\title{
The Risks of Financing Energy in Turkey: Heading for a Rocky Road
}

\author{
Esin Okay \\ Department of Banking and Finance, Faculty of Commercial Sciences, Istanbul Commerce University, Istanbul, \\ Turkey \\ Email: eokay@iticu.edu.tr
}

Received 20 November 2013; revised 20 December 2013; accepted 28 December 2013

Copyright (C) 2014 by author and Scientific Research Publishing Inc.

This work is licensed under the Creative Commons Attribution International License (CC BY). http://creativecommons.org/licenses/by/4.0/

(c) (i) Open Access

\begin{abstract}
After the implementation of Energy Efficiency Law (EEL) in Turkey, Turkish engineering firms show considerable interest in energy savings projects. There is a growing sign of an energy efficiency implementation in Turkey. However, energy importation costs of Turkey still present a challenge leading to huge financial burdens. This paper explores the energy financing in Turkey and the likelihood of risks after the establishment of structural reforms. The so-called structural problems on the agenda of Turkey are emphasized during the crisis. Actually, global crisis affected the lending conditions herein counterparty risk and restricted the relations of enterprises and banks. In this study, it is argued that there are strong barriers for the future energy saving industry in Turkey made up of macro-economic, micro-economic and financial risks coming through both domestic and global means.
\end{abstract}

\section{Keywords}

Energy Projects; Energy Saving Industry; Energy Financing; Credit Risk; Country Risk; Turkey

\section{Introduction}

There has been a great interest in energy efficiency improvement since the first oil price shock in the early seventies, and recently interest has heightened further because of the global warming effects of high energy use. This three decade long experience in implementing energy efficiency projects in the OECD countries has provided substantial documentation of both the economic and the environmental benefits of adopting energy efficiency improvement measures and policies. Yet, even in these developed economies, there remain a number of barriers to more widespread application of energy efficiency measures [1].

After the first oil crisis1973, energy service companies emerged in the United States. An energy service com- 
pany is an enterprise that fully provides integrated energy services to their customers (mainly large energy users, but also utilities), which may include implementing energy-efficiency projects (and also renewable energy projects), frequently on a turn-key basis [2]. It provides performance and savings guarantees, and its remuneration is directly tied to the energy savings achieved. Therefore, an energy service company risks its payments on the performance of equipment and services implemented. Some of them finance projects, recovering their investment cost from the resulting savings [3].

The energy consulting concept has been established first in North America at the very beginning of 80's (see authors [1] [4] [5] who reviews the US energy saving industry and the concept of energy efficiency projects). Then, the concept spreads to Europe where the energy saving industry has successfully developed in some countries, such as Germany, but not others in EU. Only after the 90s, the energy saving concept were created in developing countries. At that time, energy end-users have just went through the first energy crises and they were looking for important operation cost reductions. Many major energy customers were developing a new way to manage and monitor their energy consumption, looking to install the most efficient equipment to replace old inefficient ones. The needs for third party financing mechanism or energy service performance contracting [6] had been proposed by some engineering companies already involved in energy management, since it was perceived as one of the main barriers to implement those potential projects. So for more than 10 years, energy saving projects operated in North America and then, in a lesser way, in Europe, based mainly on the economic benefit of the proposed projects [7].

Nowadays, international authorities are looking for solutions for the increasing energy needs and environmental impact of energy consumption and energy services. World Bank has developed over three dozen projects to support the development of local energy saving industries, including Brazil, Bulgaria, China, Croatia, India, Poland, Thailand, Tunisia, Turkey, Uruguay and Vietnam. While the development of local energy saving industries can often take more than a decade, the benefits can be substantial [8]. Bertoldi, Boza-Kiss and Rezessy (2007) give an update of the status report of energy savings in Europe to investigate the specific situation in EU-27 and in some non-EU countries. The authors find the energy markets in Europe to be at diverse stages of development (Germany and Italy: large numbers of energy projects, Latvia, Romania, and Denmark: a few energy companies, Albania, Serbia, Hungary: decreasing energy market, Estonia, Greece, Belarus, and Macedonia: just getting established, Italy and France: expanding [9]. Turkey, under the regulations of EU directives, is another country that established a new energy saving industry in EU [10] [11].

Turkey concentrated on the development of energy management by General Directorate of Renewable Energy of Ministry of Energy and Natural Resources in cooperation with international organizations such as WB, EU and Japan International Cooperation Agency (JICA) since 1995 [12]. Energy industry in Turkey is endowed with rich renewable energy sources (hydro, wind, geothermal, and solar power) potential. The technically feasible potential of hydro amounts to 216 TWh/year while economically feasible potential is nearly 125 TWh/year. About $32 \%$ of the economically feasible hydro-potential has been developed, based on average annual generation [13].

After the adoption of the Energy Efficiency Law (EEL) 2007, Turkey started to conduct energy efficiency (EE) projects regarding the precautions to increase the efficiency of energy consumption by industrial establishments. There is a rapid change on the way to building up energy saving industry in Turkey. Currently there are 34 certified energy companies in Turkey. The market is made up of local capital owners with no joint venture or foreign energy company. Most of the energy projects are connected with electricity rather than oil. Despite some teething problems relating to financial support, the energy saving industry in Turkey is slowly but steadily growing. The industry conceive to finance energy-efficiency projects with the help of European Union (EU) and World Bank (WB) funds in the short run and with Turkish banks' credits in the medium to long run. For instance, the government is cooperating with the WB for supporting small hydro and wind energy projects [12].

Turkey's energy demand has been growing with a rate of $6 \%$ for decades and this demand is expected to persist as a result of rapid urbanization and industrialization. Primary energy demand has been projected to reach 220 million toe in 2020 (a 150\% increase compared to the current level). The limited availability and production capacity of domestic energy sources cause import dependency primarily on oil and gas [10]. WB has allocated 420 million US dollars credit to Turkey for supporting developments in the utilization of renewable energy sources. Two development and investment banks, in particular the Turkish Industrial Development Bank (TSKB) (75\% of the credit) will act as intermediary in the use of the credit most of which will be used for development 
of geothermal, hydro and wind energy sources. Only private sector institutions will be able to utilize the credit. The project proposals should be in conformity with the Turkish environmental legislation as well as other conditions which could be requested by the WB [14].

The organization of this paper is as follows: Section 2 briefly reviews energy saving projects and energy financing mechanisms. In Section 3, the counterparty risk and credit risk via energy financing have been presented, emphasizing the experiences in the developed and developing countries. Section 4 explores the financing of energy projects in Turkey, supporting with data of bank credits. Lastly within Section 5, the future composition and likelihood risks of energy industry in Turkey are revealed.

\section{Energy Savings and Project Financing}

The financing mechanism of energy projects is generally classified as the "guaranteed savings" and "shared savings". In the "guaranteed savings" mechanism, the energy company guarantees a certain level of energy, savings sufficient to cover clients' annual debt obligation, and protect the client from any performance risk, and the clients are financed directly by banks or by a financing agency. The client repays the loan and the credit risk stays with the lender. In countries with established banking structure, project financing, and stable economy the "guaranteed savings" mechanism functions properly [10]. Success stories are available for the UK, Austria, and Hungary [5] [15] [16].

In "shared savings" mechanism, energy company carries both the performance and credit risk. Energy company repays the loan and the credit risk stays with the company and the client assumes no financial risk. In developing countries, the "shared savings" mechanism is more suitable since it does not require clients to assume investment-repayment risk. The client assumes no financial obligation other than to pay a percentage of the actual savings to the energy company over a specified period of time. This obligation is not considered debt and does not appear on the customer's balance sheet. In such markets, there are too few energy service companies most of them small-sized. There are WB funded stories available from India, China, and Brazil [1] [17] [18]. The professionals involved with energy efficiency projects have long believed that the lack of financing mechanisms was one of the main barriers to the establishment of the industry in Brazil [18]. Most Mexican energy companies are very small engineering firms that lack capital to invest in projects. To overcome this financial barrier inte- raction with international energy companies and to seek possible business partnerships is admitted [19].

Financial barriers are found to be the lack of funds for awareness and the insufficiency of financial support of energy companies. Bannai et al. (2007) using financial derivatives and actual data from existing plants, show how the concepts and tools of financial engineering can be used to hedge the risks due to volatility of fuel and electricity costs to increase the stability of the profit associated with energy business [20].

The financing options available for energy performance contract projects are bank financing, direct customer financing, public financing (bonds), energy service companies or third party financing [10]. Whereas, the policy solutions to promote project financing need developing an International Energy Efficiency Financing Protocol (IEEFP) and creating an Energy Efficiency Projects (EEP) Financing Fund [21]. Bank financing of energy companies, instead of municipalities, is a well-accepted model which allows the entry of private capital into the sector and offers instant modernization projects. This is at minimal or no increase in costs to the municipality as energy companies receive service fees from municipalities based on energy savings achieved [22]. Similarly, The European Bank for Reconstruction and Development (EBRD) is committed to developing more efficient uses of energy within its countries of operations. One way of promoting energy efficiency improvements is through energy service companies [23].

The need for increase efficiency and environmental benefit is today even stronger in developing countries than it is in industrialized ones. Brazil, India, China [24] are probably the three best examples of those needs, and on the potential global environmental impact if these goals are not achieved. In this context, the need to investigate what are the actual barriers for the full development of this concept in countries like India is quite important [25]. The energy saving industry in India is still under evolution. Energy companies in India face a number of surmountable barriers that need to be worked on. Most of the barriers will fall with the lapse of time as the market becomes more familiar with the business, but some do need action by large organization or the government. The concept is new and not widely known. Customers are reluctant to sign long-term contracts. There are a few energy companies, most of them small-sized, in India [1]. WB is funding a project on develop- 
ing financial intermediary mechanisms for energy-efficiency investments in some countries like India. Surveys have been conducted on Indian energy saving industry, energy audit and consulting companies regarding their perception of energy companies and energy projects in India [26].

On the other hand, Hungary has been a leading model to develop the scope of energy savings as one of the most successful developing country in Europe. With a strong third party financing market, early restructuring energy sector, good institutional and banking sector reforms Hungary can be shown as a good indicator for positive results [27].

Hungary pioneered with the market-oriented restructuring of the economy, starting already in the 1980s. Within the economic reforms, it has been a leader in electricity restructuring in the region by completing a large share of unbundling, price liberalization, privatization, lifting of most subsidies, and discontinuing cross-subsidies by the late 1990s. By 2004, all non-residential electricity consumers are eligible to choose their supplier; and the gas market has been opened as well. There are about 10 - 20 key players and some other 200 more players acting in the Hungarian market. The ownership of the district heating systems was transferred to the local governments, heating stations were privatized, direct subsidies were stopped and also state owned flats were privatized. Considerable amendments have been made in the legal framework as well. Devolving statutory powers to local authorities, fiscal decentralization and rules of public budgeting related to energy savings have also greatly contributed to the development of energy saving projects in the municipal sector. Last, but not least, payment arrears and commercial losses are much less of a problem in Hungary than in the rest of the region [15].

After the change in regime, Hungary has been a prime target for various international donor and aid programs targeting energy efficiency. Many international actors, including the EBRD, the Global Environment Facility (GEF) through the International Finance Corporation (IFC), and the United State Agency for International Development (USAID), have been supportive in the promotion of energy saving industry in particular through different approaches and programs [15]. IFC addresses Hungary as an innovative model for energy market experience with decreased operating costs for companies and hence increased international competitiveness [28].

Some other factors contributed to the Hungarian success in the development of a strong energy efficiency. The requirements for EU accession meant providing a strong imperative to liberalize the energy sectors and ensure that energy prices reflect true economic costs. The requirement for lower energy intensity also exerted some pressure to trigger institutional changes in relation to the improvement of energy efficiency in the country. More recently, the ratification of the Kyoto Protocol by the EU and the accessing countries (including Hungary), forced countries to introduce policies and measures to promote reductions in greenhouse gas (GHG) emissions, which generally implies the conservation of energy, since energy consumption is by far the biggest contributor to greenhouse gas emissions and improving energy efficiency among the most cost-efficient options for GHG reduction. These measures contributed as well to the development of stronger incentives to develop the energy efficiency sector [15].

\section{Financing Risks of Energy Projects}

Economic developments after 1980's has led to an increased liberalization of markets and countries have to find other strategies to ensure the proper management of their projects and investments. Nowadays, there is a huge potential of risks through liberalization endangering the economic and financial system. Therefore, sectors in economies do vary within the scope of this new political order, so as the energy sector's fall [6].

Energy companies have strong transition impact as a private sector instrument to deliver energy savings. In this respect, the role of enabling policies should be noted in national energy policy act, state regulations for performance contracting and utility programs. These companies may finance or assist in arranging financing for the operation of an energy system by providing a savings guarantee. Energy service companies operate under an energy performance contracting arrangement, whereby they implement a project to deliver energy efficiency, or a renewable energy project, and use the stream of income from the cost savings, or the renewable energy produced, to repay the costs of the project [23].

Energy savings performance contract is designed to establish energy efficiency projects. Third party financing is the most commonly used type for energy projects and it can be realized by a guaranteed saving contract. Country risk, credit risk and counterparty risk play a major role via projects with too high level of risk as for the case with energy projects. So, energy financers should have strong balance sheets. They must have strong assets 
to take on huge liabilities of clients that have long-term projects. This is extremely a big risk that points to a considerably significant size-based balance sheet to finance projects. Therefore, energy companies should be committed to risk management, as well. Energy projects should be managed with risk reduction methods like hedging instruments and venture capital. Therefore, when energy companies need financial support to invest such risky projects banks analyze detailed financial statements before extending credit. Besides, banks should implement BASEL II, and then BASEL III. The purpose of BASEL II-III risk implementations is to create an international standard that banking regulators can use when creating regulations about how much capital banks need to put aside to guard against the types of financial and operational risks banks face. BASEL III is a response to prevent the weaknesses in the BASEL II framework where it will lead tightening the risk management approach. BASEL III is expected to be implemented globally between 2013 and 2019 [29]. BASEL III could tighten banks' provision of long-term finance or result in increased interest rates. Either of these changes and tightened capital and liquidity requirements are likely to limit the amount of capital available for renewable energy financing from banks in the future. Together, these are threats to renewable energy deployment because limited financing may prevent the energy projects [30].

Similarly, energy companies should anticipate macroeconomic factors of the country, foreseeing the risks [21]. Country risk covers credit risk, as both refers to investing in a country. For example, the Country Risk Assessment Model (CRAM) of OECD produces a quantitative assessment of country credit risk based on three groups of risk indicators (the payment experience of the participants, the financial situation and the economic situation) [31]. Credit risk is the risk of loss due to default by a counterparty on its contractual obligations, or as a result of reduction in the credit quality of the counterparty [32]. So, in case of energy investment projects with high risk credits the country risk is highlighted. Counterparty credit risk is the risk that the counterparty to a financial contract will default prior to the expiration of the contract and will not make all the payments required by the contract. Only the contracts privately negotiated between counterparties-over-the-counter derivatives and security financing transactions-are subject to counterparty risk. Exchange-traded derivatives are not affected by counterparty risk, because the exchange guarantees the cash flows promised by the derivative to counterparties. Counterparty risk is similar to other forms of credit risk in that the cause of economic loss is obligor's default. There are, however, two features that set counterparty risk apart from more traditional forms of credit risk: The uncertainty of exposure and bilateral nature of credit risk [33].

Third-party finance (banks or special funds) can be used to provide customers with the required funds to pay for these projects, isolating the energy company from credit risk as depicted in Figure 1 on the part of the customer. The guaranteed savings scheme is likely to function properly only in countries with an established banking structure, high degree of familiarity with project financing and sufficient technical expertise, also within the banking sector, to understand energy-efficiency projects (e.g. the UK, Austria, and more recently, Hungary) [16]. Financing may be provided by a separate financial sub-division of the energy industry for larger projects with

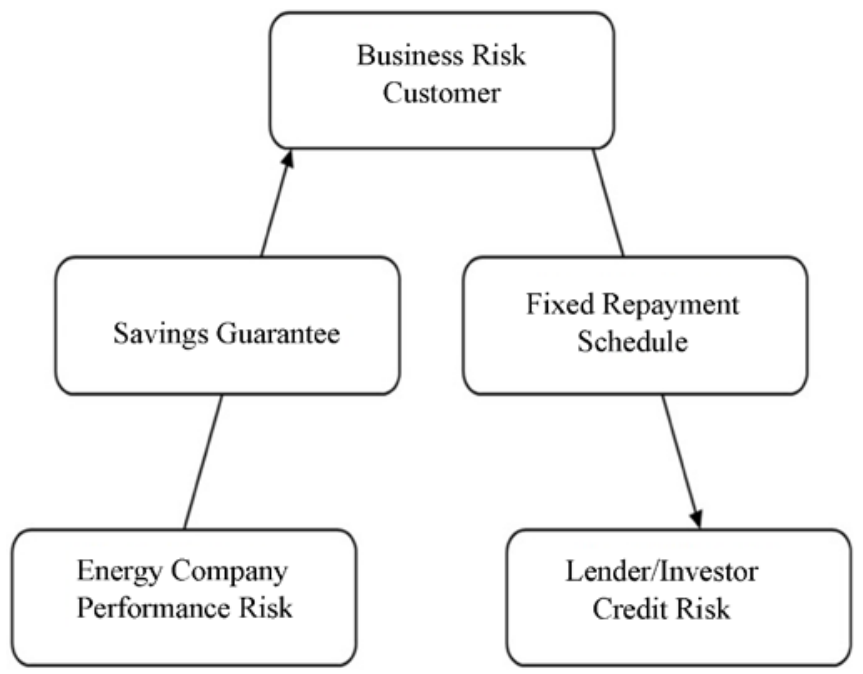

Figure 1. Guaranteed Savings (GS) financing mechanism of performance contracting in energy projects [35]. 
either good default options or external guarantees provided by the government or trustworthy international lenders [34].

The interest and co-operation of financial institutions and banks are essential for energy market development financing of individual projects. Government and donor agencies can stimulate the market for affordable financial options through various means: Soft loans or grants for projects and energy business expansion, support to demonstration projects for information dissemination, information and education programs for financiers to ensure they understand the financial soundness of energy efficiency projects, evolving appropriate financial guarantee mechanism against loans [21].

Energy services projects, in all their varying forms, are technically complex undertakings, requiring significant design, engineering and development efforts to create a transaction that is economically compelling to the end user customer. However, all these efforts could be for naught if third party financing is required and the transaction is not structured to satisfy the requirements of the capital markets. Developing a bankable energy services transaction requires a thorough understanding and balancing of the needs and objectives of the three main parties to the deal-the customer (end user or obligor), the energy company, and the lender. Obligor credit risk is the core risk for all financing transactions and simply translates to the end user's ability to satisfy all of its obligations (payment and otherwise) under the terms of the transaction. Despite the wide variety of financing structures for energy services transactions, their common foundation is the end user's obligation to make payments in exchange for the products or services received. In whatever forms it takes (i.e. lease payment, loan payment, services payment, usage payment, etc.), that payment obligation provides the lender's primary source of debt service and return on the equity investment, if any. As a result, the bulk of the lender's underwriting activities are focused on a detailed analysis of the end-user's overall credit profile. Operating performance, cash flow, debt service capacity, liquidity, balance sheet strength, market position, management capabilities, and future projections are among the many factors thoroughly examined during the underwriting process. In order to achieve the desired end result, i.e. transaction approval, the credit analysis must conclude that the obligor is capable of fully satisfying its obligations throughout the full term of the transaction [36].

Most facility managers agree that energy management projects are good investments. Generally, energy projects reduce operational costs, have a low risk/reward ratio, usually improve productivity, and even have been shown to improve a firm's stock price. Despite these benefits, many cost-effective energy projects are not implemented due to financial constraints. A study of manufacturing facilities revealed that first-cost and capital constraints represented over 35\% of the reasons cost-effective energy projects were not implemented. Often, the facility manager does not have enough cash to allocate funding or cannot get budget approval to cover initial costs. Financial arrangements are one way to mitigate risks of a facility's funding constraints, allowing additional energy savings to be reaped.

Loans have been the traditional financial arrangement for many types of equipment purchases. A bank's willingness to loan depends on the borrower's financial health, experience in energy management, and number of years in business. Obtaining a bank loan can be difficult if the loan officer is unfamiliar with energy projects. Loan officers and financiers may not understand energy-related terminology. In addition, facility managers may not be comfortable with the financer's language. Thus, to save time, a bank that can understand energy projects should be chosen. Most banks will require a down payment and collateral to secure a loan. However, securing assets can be difficult with energy projects, because the equipment often becomes part of the real estate of the plant. For example, it would be very difficult for a bank to repossess lighting fixtures from a retrofit. In these scenarios, lenders may be willing to secure other assets as collateral [37].

\section{Energy Financing in Turkey}

Turkey's energy market is sponsored by government and WB funds during its incubation stage under the shared savings mechanism (SS) is depicted in Figure 2. As stated before, under a shared savings the energy company assumes both performance and credit risk (as the client takes over some performance risk, it will try to avoid assuming any credit risk) [16] [21].

Creating a competitive, mature energy market like Hungary (as a developing country model, has more than 200 energy service companies) through the GS mechanism as depicted in Figure 1, is not possible under today's Turkish economic environment. The SS concept is a good introductory model in developing markets because customers assume no financial risk, which they like or even demand. The downturn of this structure is that it 


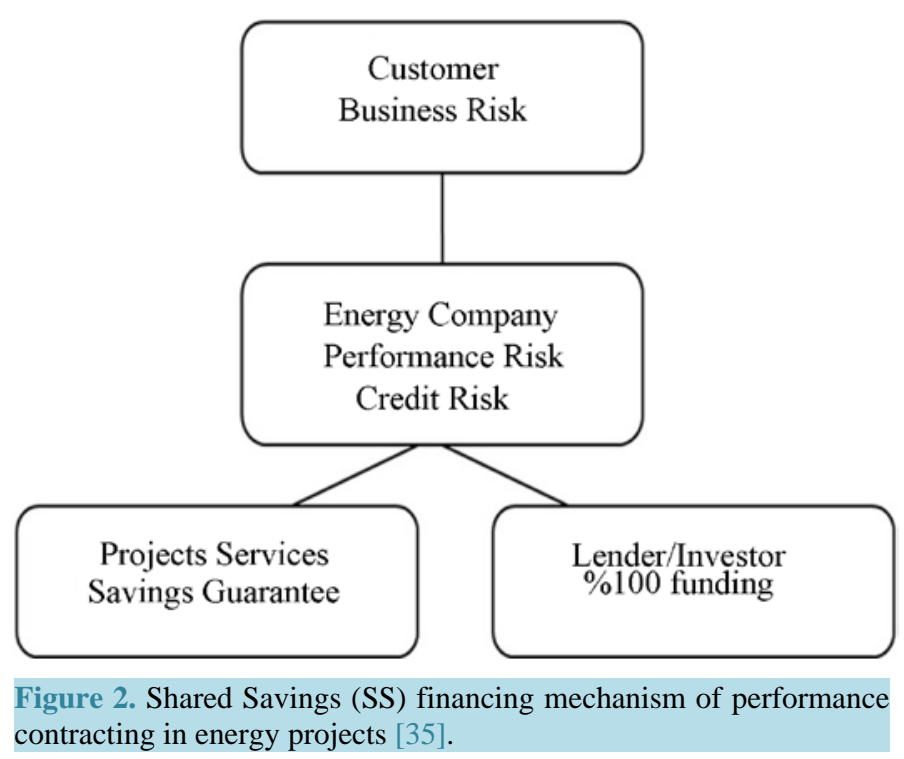

limits long-term market growth and competition between energy companies and between financing institutions because small and/or new companies with no previous experience in borrowing and few own resources are unlikely to enter the market if such agreements dominate [38].

Nowadays, there are 13 domestic banks in Turkey proposing credits to enter the energy efficiency market. Most of them are commercial and the rest are state banks [12]. The energy projects and the credits financing in Turkey had a volatile trend throughout the decade coinciding with two crises (domestic crisis; 2000-2001 banking crisis and 2008 global crisis). The government unfolded privatization projects in early 2000's, primarily the energy projects to fulfill household requirements like natural gas contracts and electricity contracts.

Therefore, from late 2000 to early 2004, the share of energy credits rapidly went up high reaching approximately up to $14 \%$ around 2002-2003 as depicted in Figure 3. The share of energy credits are calculated from the set of data obtained from Central Bank of the Republic of Turkey, concerning years (2000-2013). Relatively, weak energy credit flows have seemingly been constrained by the 2000-2001 banking crisis in Turkey. After the crisis, the flows recovered a bit but falling gradually under $10 \%$ by 2004 energy credits continued to diminish until 2008. Later, when the implementation of EEL enhanced the energy projects in Turkey, the share of credits started to rise again up to about 7\%, but not so compromising till 2013 as depicted in Figure 3, in the shadow of the ongoing global crisis and majorly country risk that will be discussed in the next section. The current situation of energy saving industry shows a low profile performance and a considerable credit risk due to micro-economic and financial situation in Turkey. Eventually, this points to future risks of energy industry in Turkey.

\section{The Present and Future Risks in Turkey}

First of all, the energy market in Turkey is exposed to macro-economic problems (country risk). Country's current low interest rate and low inflation potential due to small debt-to-GNP ratio unlocks the potential for growth in this sector. However, large debt problems of the developed countries and a worldwide fear of risk may block the foreign direct investment (FDI) flow that is necessary for the progress of the market as well for the reduction of the country's current account deficit. Turkey has persistent and risky current account deficits for years. This risk as a destabilizing factor for Turkish Economy has been studied in many papers. Turkey is exposed to macroeconomic instability, financial fragility and crisis in the case of internal and external economic and political shocks, because of the structural economic problems-low productivity and global competitiveness level in high-technology products, foreign dependency in energy, intermediate goods and finance, domestic saving gapresulting in unsustainable current account deficit [40]-[42].

After the 2008-2009 global financial crisis, the chronic problem of the Turkish Economy, the current account balance trouble recrudesced. In the present instance, the factors increasing the current account balance are thought not only structural problems but also economic conditions, booming international credit inflows from global markets appreciating the Turkish Lira, deteriorating the current account balance steeply [43]. FDI neces- 


\section{ENERGY CREDITS \%}

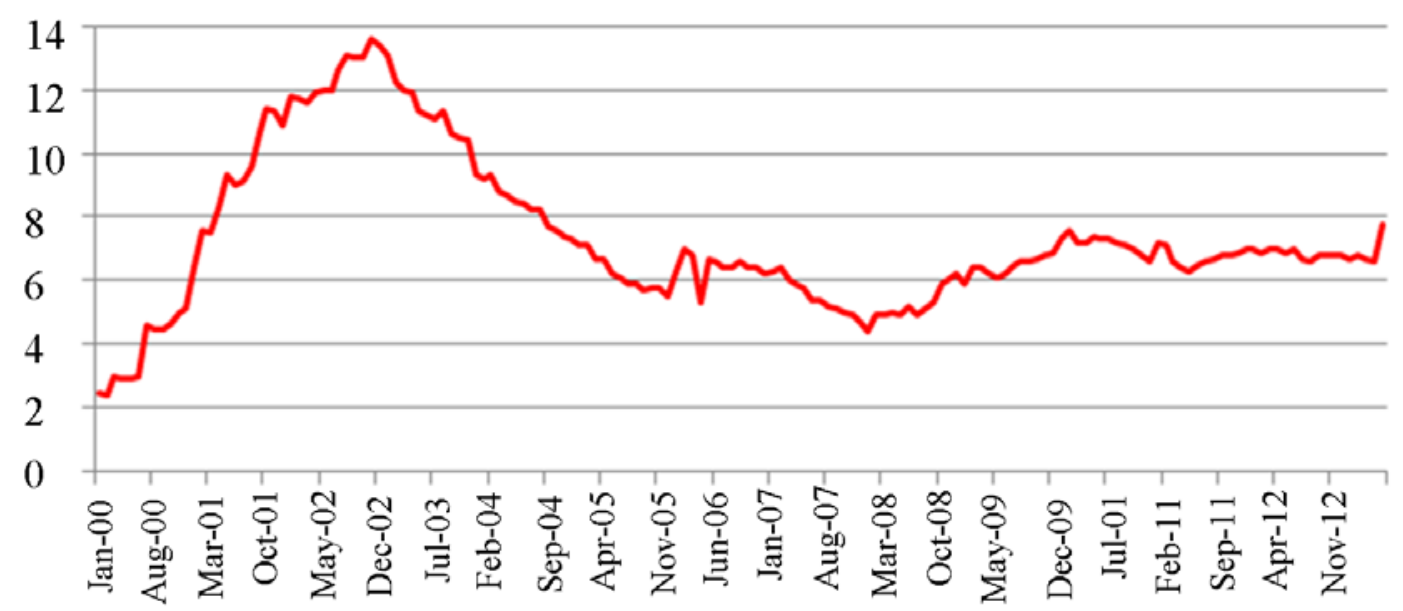

Figure 3. Energy Credits (percentage share \%) [39].

sity is highlighted as the current account deficits enhanced after the crisis.

Soytas and Sari (2009) mention that Turkey is facing an investment problem and regardless of which alternative energy sources she wants to develop or utilize a large portion of this investment would be through accumulating capital based on imported technology [44]. The role of Turkey's energy market and its relationships with the universities and research \& development centers had been given by [10]. It is stated that the Turkish government must support and develop a shared vision of energy-related innovation between industry, universities, government-based research \& development centers, energy companies, and related (FDI). Turkey's problem with FDI is that current account deficit (CAD), in which energy imports contribute significantly, is large and getting larger (Central Bank of the Republic of Turkey, CBRT, http://evds.tcmb.gov.tr); restricting the motivation of long-term FDI. Realization of ES potential via energy-related innovations should help reduce this portion of the CAD, and in turn, should encourage FDI flow to the country. Reduction in the CAD via successful energy-related innovations is expected to create an induced positive recurring effect on FDI flow. It is very important not only, to design efficient exchange rate policy in connection with the monetary, the fiscal and the external finance policy but also, to improve global competitiveness, credibility and investment climate in order to achieve sustainable current account balance and economic growth in the long run for the Turkish Economy. Otherwise, under the challenging conditions of global competitiveness, the Turkish Economy may suffer from unsustainable high current account deficits in the future [43].

Especially, to maintain a lower credit risk of financing energy market, it is a must to align with international energy companies and to seek possible business partnerships, securing third party financing from international finance organizations (beyond WB) such as IFC, Environmental Enterprises Assistance Fund (EEAF) and the Renewable Energy Equity Fund (REEF).

Despite the banking sector's high liquidity and profit after the adoption of BASEL II, lending volumes remain depressed. This is primarily because of the risk-averse approach of the new banking system and contrarily much attributed private sector and its capital inadequacy. Unfortunately, BASEL II was not implemented by the private sector in Turkey. The unsuccessful implementations of the BASEL II for the small and medium sized firms in Turkey show that companies are not apt to implement risk management.

Turkish private sector-consisting of 99\% small and medium sized (SMEs)-maintains the effects of weaknesses and inadequacies for years that provide insight on the limits to firm growth and sustainable investment. By all means, SMEs, being small in size and having structural problems, cannot bear the entire financial risk of energy projects. In Turkey, government and KOSGEB collectively provide tax incentives, subsidies and lending programs for SMEs [45]. But because companies are not apt to adopt the generally accepted rules of management the problems still continue. Therefore, only large-sized firms are on the platform to establish an energy market. If they come together to form joint ventures with domestic firms or established foreign energy compnaies the result might change. If not, then energy financers should have strong balance sheets, as stated before. 
Energy companies must have strong assets to take on huge liabilities of clients that have projects of 7 - 10 years. This is an extremely a big risk that points to a considerably significant size-based balance sheet to finance projects. Therefore, they should be committed to risk management. Energy activities should be managed with risk-reducing methods like hedging instruments and venture capital. Also, for secured loans, it is important to assess the end-user payment default risk, energy company non-performance risk and bank’s loan-repayment default risk. These risks are to be appropriately addressed in order to ensure successful projects.

However, companies in Turkey do not use risk management tools effectively. Without risk management, SMEs in Turkey especially have to bear size risk, credit risk, capital inadequacy, regulation risk, technology risk and country risk. They have problems of coping with the generally accepted accounting and financial standards that especially lead to poor management of assets and liabilities. With the lack of SMEs-that constitutes 99\% percent of private sector-the Turkish energy market is inevitably is small. In such a market, candidate energy companies in Turkey-with poor assessment of risk culture-will not be ready for GS financing mechanism. After all, with a finalized adoption of BASEL II in Turkey, banks may resist financing energy projects because of the risky nature of this business. What's more, as the arrival of BASEL III is still unknown in private sector, the new accord could again tighten banks' provision of long-term finance [30]. While this is a coming threat to energy markets all over the world, it could ruin the progress of Turkish energy savings.

Similarly, another concern of SMEs will be shaping the future of energy market and energy efficiency projects. That is, an update in legal regime and norms should affect energy partners and projects which will in turn help in cooperation with foreign capital and companies to compete. In 2012, a new legislation was prepared in accordance with current legal and regulatory requirements. This legislation, called as new Turkish Commercial Code No.6102 [46], aims to force the companies to follow the generally accepted standards of accounting and auditing, transparency, eventually increasing level and change the investment environment for good. It will help to increase corporate governance and transparency level for better investment conditions. Although, a new regulation is issued in July 2012 for implementing accounting standards (in line with the international standards) to evaluate the Turkish companies, there will surely be a need of time to adapt to this new situation. The companies will be subject to the new Turkish Accounting Standards in line with the International Financial Reporting Standards on 1 January 2013 [46]. Until then up to the actual deadline for adapting given by the government, July 2014, there will still be poor measurement and inadequate accounting system for companies in Turkey, which in the end apply for the energy companies. This seems to be a long period after July 2014. The concerns will continue as poor measurement and auditing problems lead to transparency inadequacy, lack of creditworthiness and corporate governance which mean risky for prospective partners—mostly foreign ones—of energy companies (credit risk and regulation risk).

Certainly, the updated legal formalities are expected to provide a more predictable and well-designed system with stimulating policies in the near future. The modern legislative change will welcome foreign capital to the new market just like the case for the Turkish Financial Markets. At least, the target of the government is to take a path leading a similar result. The Turkish banking and mostly the Turkish insurance market happened to be the subject of the foreign capital lately. After the legislative transformation, in a few years of time, foreign capital owners rapidly invested in the Turkish insurance companies. Today, the percentage of foreign capital in the Turkish insurance sector is nearly 90\%. But it should be noted that aside from the private sector enterprises, financial companies were subject to a complete transformation in corporate governance, accounting standards, risk management regulations. The rapid attraction of foreign capital to financial companies is explicable because of the highly standard financial system with modern legislations. Nevertheless, the case of financial system and efforts of financial institutions stand far beyond the SMEs in Turkey. Actually, the composition of restructuring fully needs both sides the mutually related financial sector and private sector at the same time.

Beyond such financial and risk-related issues there are not any technical-/engineering-related barriers since many Turkish private companies have already proved their qualifications by completing very successfully especially the large-scale housing as well as industrial construction projects abroad. On the other hand, there is no opportunity for the energy companies in street-lighting or similar tasks as such projects are handled by the municipalities in Turkey. So, energy companies should engage in energy-related research and development and innovations. Literature reveals that energy/emission improvements of countries may be related to their innovation and research and development-activity levels [47].

Despite ongoing changes, there is still a lack of knowledge on energy market and its facilities. Therefore, the government must enforce energy campaigns likewise incentives and investment support programs strengthened 
with universities and technical schools. With a lack of information and campaigns, it will be hard to erase low awareness. Especially all of the positive legislative change will have no valueable effect on the development of the market. Among all the state universities of Turkey, only Gazi University applied for the training tasks and was approved by the EIE in February 2011. There is no information on whether any other universities had applied to become energy-related centers. It is assumed that the number of such universities will not exceed three to five in the near future [11].

In the light of the barriers, the situation shortly points to an inevitable halt in progress of the energy market in Turkey. Large current account deficits, uncompleted structural reforms, unfinished privatizations make the creation of a mature, perfectly competitive energy market suspicious. It's clear that no progress could be obtained until Turkey provides a further modernization of law system adopting legal reforms and gains improved results.

\section{Conclusions and Recommendations}

The recent Energy Efficiency Law (EEL) has an important potential to further develop renewable energy in Turkey. But there are strong barriers for the future energy industry in Turkey. All the assessment of domestic risks including credit risk, country risk, financing risk and regulation risk show that Turkey is not fully ready for building an energy saving marketing. The share of energy sector credits shows a low profile due to micro-economic and financial risks in Turkey. Eventually, this points to future risks of financing energy projects in Turkey.

Turkey must direct its limited energy-policy related funds primarily to the private sector exhibiting high energy consumption, high energy efficiency potential, and high competence in research \& development and innovation activities. Innovation flourishes as a consequence of knowledge accumulation and research \& development experience, all of which also expedite compliance with laws and regulations. The new efficiency law of Turkey offers many opportunities and solutions to problems of energy savings industry:

1. for foreign energy companies to enter the new Turkish energy market;

2. for domestic energy companies to increase business volume with industrial, electricity, transportation, and construction sectors and to undertake joint ventures with foreign energy companies;

3. for Turkish universities in establishing new or developing the existing energy and energy-efficiency related institutes, departments, degree-granting programs, and EEL-related "official certificate" programs;

4. for Turkish universities in acquiring commercial and state funds to support academic research projects and faculty members, and in establishing new or raising the existing collaborations with the foreign universities in energy-efficiency related academic areas; and

5. for "domestic and foreign banks" and "credit companies" in the long-and medium-run financing of Turkish companies in their energy-efficiency related projects entailed by the EEL.

Turkish economy recovered quickly from the precipitous drop in output triggered by the 2008 global crisis. However, the crisis shortening of liquidity changed the conditions of economic units, tightened lending and led to shift in investment factors. Despite the banking sector's high liquidity and profit, lending volumes remain depressed. This is primarily because of the risk-averse approach of the new banking system and contrarily the attributed but so unfruitful private sector and its capital inadequacy. Turkish private sector (merely the SMEs) having structural problems and institutional risks of adapting regulations-maintains the effects of weaknesses and inadequacies for years that provide insight on the limits to company growth and sustainable investment. This situation has been more severely disrupted by the crisis.

By all means SMEs, being small in size, cannot bear the entire financial risk of projects, as stated before. Therefore, only large sized firms are on the platform to establish an energy market. If they come together to form joint ventures with domestic firms or either established foreign energy companies the result might change. Without foreign capital, with merely the support of international financial institutions, the market will not be able to prosper because this is primarily a risk-based capital system that Turkey is trying to master. One of the most important difficulties that local companies face in Turkey is capital inadequacy, and therefore, they are insufficient to act as market-makers. Since 2005, international partners have seen some potential of a stable economy and good indicators, free from country risk, to invest and they are more willing to invest in this promising sector. At the same time for secured loans, it is important to assess the end-user payment default risk, energy company non-performance risk and bank's loan repayment default risk. These risks are to be appropriately addressed in order to ensure successful projects. What's more, energy projects need stable economic 
environment with low interest rate and inflation.

The energy projects in Turkey may be smaller than those in the industrial sector. To develop a prosperous energy market which determines counterparty and liquidity risk, it should be noted that macro-economic, microeconomic and financial factors are now subject to additional influences like global liquidity concerns. Therefore, the future Turkish energy market is somehow complicated made up of macro-economic, micro-economic and financial risks coming through both domestic and global means. Unfortunately, market performance is bound to market size problem, high interest rates, loan security problem which are severe constraints that might block the progress of the market. Especially, to maintain a lower credit risk of financing energy projects, it is a must to align with international energy companies and to seek possible business partnerships, securing third party financing from international finance organizations beyond WB such as the IFC, EEAF and the REEF. Beyond, the management of financial burdens there is a need of administration and enforcement of all the related legislation and requirements in order to obtain a secure future of energy in Turkey.

\section{References}

[1] Athale, S. and Chavan, M. (2008) ESCOs: The Need of the Hour for Energy Efficiency in India. The Bulletin on Energy Efficiency, 8, 34-35.

http://www.docstoc.com/docs/26030648/ESCOs_-The-need-of-the-hour-for-Energy-Efficiency-in-India

[2] Hopper, N., Goldman, C. and Mcwilliams, J. (2005) Public and Institutional Markets for ESCO Services: Comparing Programs, Practices and Performance. Ernest Orlando Lawrence Berkeley National Laboratory, Berkeley. http://emp.lbl.gov/sites/all/files/REPORT\%20lbnl\%20-\%2055002.pdf

[3] Bertoldi, P., Berrutto, V., de Renzio, M., Adnot, J. and Vine, E. (2003) How Are EU ESCOs Behaving and How to Create a Real ESCO Market? Proceedings of the European Council for Energy Efficient Economy, Stockholm, 2-7 June 2003, 909-916. http://www.eceee.org/library/conference_proceedings/eceee_Summer_Studies/2003c/Panel_5/5041bertoldi/paper

[4] Osborn, J., Goldman, C., Hopper, C. and Singer, T. (2002) Assessing US ESCO Industry: Results from the NAESCO Database Project ACEEE Summer Study on Energy Efficiency in Buildings. Ernest Orlando Lawrence Berkeley National Laboratory, Berkeley.

http://emp.lbl.gov/publications/assessing-us-esco-industry-results-naesco-database-project

[5] Goldman, C. (2003) Overview of US ESCO İndustry: Recent Trends and Historic Performance. International Workshop on Energy Efficiency Services Industries, Shanghai, 8 September 2003, 1-33.

[6] Silvoni, R. (2007) ESCO and Third Party Financing. IInd Seminar of Information Campaigns, Plovdiv, 5 March 2007, $1-14$.

http://www.seea.government.bg/documents/twinning/information campaign B 5 mar 06/information campaign 2b. pdf

[7] Sghaier, M. (2007) The Energy Audit in Tunisia and İts İnteraction with the ESCO Development Strategy. NEEP, Workshop: Discovering Business Opportunities in the Energy Services Industry. Northeast Energy Efficiency Partnerships (NEEP), Pasadena,

http://www.neep.org.sa/en/downloads/workshops/w02/w02_19_sghaier_paper_(en).pdfCherail)

[8] Sarkar, A. and Jas, S. (2010) Financing Energy Efficiency in Developing Countries_Lessons Learned and Remaining Challenges. Energy Policy, 38, 5560-5571. http://dx.doi.org/10.1016/j.enpol.2010.05.001

[9] Bertoldi, P., Boza-Kiss, B. and Rezessy, S. (2007) Latest Development of Energy Service Companies across Europe-A European ESCO Update. European Commission Joint Research Centre, Institute Environment and Sustainability, Ispra. www.energy.eu/publications/LBNA22927ENC_002.pdf

[10] Akman, U., Okay, E. and Okay, N. (2013) Current Snapshot of the Turkish ESCO Market. Energy Policy, 60, 106-115. http://dx.doi.org/10.1016/j.enpol.2013.04.080

[11] Okay, E., Okay, N. and Akman, U. (2012) Turkey Chapter. In: Langlois, P. and Hansen, S.J., Eds., World ESCO Outlook, The Fairmont Press, Lilburn, 396-403.

[12] EIE (Elektrik İşleri Etüd) (2013) General Directorate of Renewable Energy of Ministry of Energy and Natural Resources. http://www.eie.gov.tr

[13] Benli, H. (2013) Potential of Renewable Energy in Electrical Energy Production and Sustainable Energy Development of Turkey: Performance and Policies. Renewable Energy, 50, 33-46. http://dx.doi.org/10.1016/j.renene.2012.06.051

[14] TSKB (Türkiye Sınai Kalkınma Bankası, Industrial Development Bank of Turkey) (2013) Energy Efficiency. http://en.tskbenerjiverimliligi.com/energy-effiency-and-tskb/sources-of-funding-and-criteria.aspx 
[15] Ürge-Vorsatz, D., Langlois, P. and Rezessy, S. (2004) Why Hungary? Lessons Learned from the Success of the Hungarian ESCO İndustry. Proceedings of the 2004 ACEEE Summer Study on Energy Efficiency in Buildings, Asilomar, 2004, 348-353. http://www.eceee.org/library/conference_proceedings/ACEEE_buildings/2004/Panel_6/p6_30/paper

[16] Bertoldi, P. and Rezessy, S. (2005) Energy Service Companies in European Countries: Status Report 2005. European Commission, Ispra.

[17] Kostka, G. and Shin, K. (2011) Energy Service Companies in China: The Role of Social Networks and Trust. Frankfurt School—Working Paper Series. http://www.frankfurt-school.de/clicnetclm/fileDownload.do?goid=000000302332AB4

[18] Morel, A. (2008) Terminal Evaluation of Project on "Developing Financial Intermediation Mechanisms for Energy Efficiency Projects in Brazil, China and India”. UNEP (United Nations Environment Programme). http://www.unep.org/eou/Portals/52/Reports/Energy_Efficiency_in_Brazil-China-India.pdf

[19] Lamers, P., Vollrad, K. and Anja, K. (2008) International Experiences with the Development of ESCO Markets. CONAE \& GTZ, Berlin. http://www.gtz.de/de/dokumente/en-International-Experience-Developing-ESCO-Markets.pdf

[20] Bannai, M., Tomita, Y., Ishida, Y., Miyazaki, D., Akisawa, A. and Kashiwagi, T. (2007) Risk Hedging against the Fuel Price Fluctuation in Energy Service Business. Energy, 32, 2051-2060. http://dx.doi.org/10.1016\%2fj.energy.2007.05.003

[21] Okay, E., Okay, N., Konukman, A.E.S. and Akman, U. (2008) Views on Turkey’s Impending ESCO Market: Is It Promising? Energy Policy, 36, 1821-1824. http://dx.doi.org/10.1016/j.enpol.2008.02.024

[22] IFC (2006) Finance For Energy Efficient Street Lighting. www.ifc.org/ifcext/gfm.nsf/AttachmentsByTitle/FMS-EO-EEF-EESL/\$FILE/FMS-EO-EEF-EESL.pdf

[23] EBRD (European Bank for Reconstruction and Development) (2005) Financing ESCOs in Transition Economies. http://www.docstoc.com/docs/27595905/Financing-ESCOs-in-Transition-Economies-\%5BEBRD---Energy-efficiency $\underline{\% \mathrm{D}}$

[24] Shen, B., Price, L., Wang, J. and Li, M. (2012) China’s Approaches to Financing Sustainable Development: Policies, Practices, and Issues. Ernest Orlando Lawrence Berkeley National Laboratory, Berkeley. http://china.lbl.gov/sites/all/files/lbl-5579e-green-finance-wiresjune-2012.pdf

[25] BDA (Bangalore Development Authority) (2004) Municipal Street Lighting Energy Saving Project. http://www.teriin.org/nss/PDDs/project4.pdf

[26] Vine, E. (2005) An International Survey of the Energy Service Company (ESCO) Industry. Energy Policy, 33, $691-704$. http://dx.doi.org/10.1016/j.enpol.2003.09.014

[27] Bertoldi, P., Rezessy, S. and Vine, E. (2006) Energy Service Companies in European Countries: Current Status and a Strategy to Foster Their Development. Energy Policy, 34, 1818-1832. http://dx.doi.org/10.1016/j.enpol.2005.01.010

[28] IFC (International Finance Corporation) (2013) Hungary Energy Efficiency: An Innovative GEF Project. FTF Brazil. http://3countryee.org/RoundTable/HungaryEE.pdf

[29] BIS (Bankingfor International Settlements) (2013) Progress report on Basel III implementation. http://www.bis.org/publ/bcbs232.pdf

[30] Narbel, P.A. (2013) The Likely Impact of Basel III on a Bank’s Appetite for Renewable Energy Financing. NHH (Norges Handelshøyskole), Bergen. http://www.nhh.no/Files/Filer/institutter/for/dp/2013/1013.pdf

[31] OECD (2013) Country Risk Classification. http://www.oecd.org/tad/xcred/crc.htm

[32] UniCredit (2013) Credit Risk. https://www.unicreditgroup.eu/en/investors/risk-management/credit.html

[33] Pykhtin, M. and Steven, Z. (2007) A Guide to Modelling Counterparty Credit Risk. GARP Risk Review, 37, 16. http://mhderivativesolutions.com/wp-content/uploads/2013/09/ssrn-id1032522.pdf

[34] Kleindorfer, P. (2010) Risk Management for EE Projects in Developing Countries. INSEAD Working Paper. http://www.insead.edu/facultyresearch/research/doc.cfm?did=43993

[35] IET (Institute for Energy and Transport of European Commision) (2013) Energy Performance Contracting. http://iet.jrc.ec.europa.eu/energyefficiency/european-energy-service-companies/energy-performance-contracting

[36] Thomas, J. (2009) Key Risk and Structuring Provisions for Bankable Transactions, Energy Project Financing: Resources and Strategies for Success. The Fairmont Press, Lilburn.

[37] Woodroof, A.E. (2009) Financing Energy Management Projects, Financing Energy Management Projects: Resources and Strategies for Success. The Fairmont Press, Lilburn.

[38] de Boer, S. (2011) Views on the Emerging Dutch ESCO Market: Can It Become Successful? Utrecht University, 
Utrecht. http://www.eukn.org/dsresource?objectid=326773\&type=org

[39] Central Bank of the Republic of Turkey, 2013. www.tcmb.gov.tr

[40] Özatay, F. (2006) Cari İşlemler Dengesine İlişkin İki Yapısal Sorun ve Mikro Reform Gereği. Uluslararası Ekonomi ve Dış Ticaret Politikalarl, No. 1, 38-50.

[41] Akçay, C. and Üçer, M. (2008) A Narrative on the Turkish Current Account. The Journal of International Trade and Diplomacy, 2, 211-238.

[42] Yükseler, Z. (2011) Türkiye'nin Karşılaştırmalı Cari İşlemler Dengesi ve Rekabet Gücü Performansı (1997-2010 Dönemi). TCMB Booklets, Central Bank Of Turkey, Ankara.

[43] Okay, E., Baytar, R. and Sarıdoğan, E. (2012) The Effects of Exchange Rate Changes on the Main Macroeconomic Variables in the Turkish Economy: An Econometric Analysis. İktisat İsletme ve Finans Dergisi, 27, 79-101.

[44] Soytas, U. and Sari, R. (2009) Energy Consumption, Economic Growth, and Carbon Emissions: Challenges Faced by an EU Candidate Member. Ecological Economics, 68, 1667-1675. http://dx.doi.org/10.1016/j.ecolecon.2007.06.014

[45] KOSGEB (2013) Energy Efficiency Project in the SMES in Turkey. http://www.kosgeb.gov.tr/Pages/UI/Baskanligimiz.aspx?ref=107

[46] Turkish Commercial Code No. 6102, 2013. www.resmigazete.gov.tr/eskiler/2011/02/20110214-1-1.htm

[47] Okay, N. and Akman, U. (2010) Analysis of ESCO Activities Using Country Indicators. Renewable and Sustainable Energy Reviews, 14, 2760-2771. http://dx.doi.org/10.1016/j.rser.2010.07.013 